\title{
Novel pathway of iron-induced blood coagulation: implications for diabetes mellitus and its complications*
}

\author{
Boguslaw Lipinski ${ }^{1}$, Etheresia Pretorius ${ }^{2}$ \\ 1 Joslin Diabetes Center, Harvard Medical School, Boston, United States \\ 2 Department of Physiology, Faculty of Health Sciences, University of Pretoria, Arcadia, Republic of South Africa
}

\section{KEY WORDS}

diabetes, fibrinogen, hydroxyl radicals, iron, polyphenols
Correspondence to:

Boguslaw Lipinski, PhD, Joslin Diabetes Center, One Joslin PI., Boston, MA 02215, USA, phone: +1-617-527-1395, fax: +1-617-309-2667, e-mail: b.lipinski2006@rcn.com Received: October 28, 2011

Revision accepted: February 3, 2012 Conflict of interest: none declared. Pol Arch Med Wewn. 2012; 122 (3): 115-122 Copyright by Medycyna Praktyczna, Kraków 2012

*In memory of Zofia Kuratowska, MD, $\mathrm{PhD}$, Ambassador of Poland to South Africa (1997-1999).

\section{ABSTRACT}

Fibrinogen (FBG) is a high-molecular-weight protein and precursor to the enzymatically formed fibrin. It has been recently discovered that FBG can be converted into an insoluble, fibrin-like polymer by a nonenzymatic action of hydroxyl radicals (HRs). These free radicals are generated due to the reaction between hydroxyl groups of water and trivalent ferric ions without the participation of any redox agent. The interaction between HRs and FBG occurs in a purified system, as well as in human plasma and in whole blood. Scanning electron microscopy (SEM) of thrombin-induced fibers and those generated with ferric chloride has shown substantial differences in their morphology and susceptibility to enzymatic degradation. Fibrin strands caused by thrombin are thick and easily digested with chymotrypsin. By contrast, the dense matted deposits formed from FBG in the presence of ferric ions are remarkably resistant to proteolytic and chemical degradations due to the presence of intermolecular hydrophobic bonds. Thus, we postulate that this iron-catalyzed reaction represents a novel blood coagulation pathway operating in degenerative diseases. By means of SEM, we showed the presence of dense fibrin-like deposits in the blood of diabetic patients. Therefore, the prothrombotic state and cardiovascular complications observed in diabetes can be explained in terms of the persistent in vivo action of free iron. This phenomenon may explain hemorheologic disturbances in patients with metabolic syndrome and other diseases caused by iron overload. Of note, HRs can be effectively scavenged by phenolic substances; therefore, certain natural polyphenolic substances, which also scavenge HRs, may be considered to have a potential antidiabetic effect. Moreover, natural or synthetic iron-binding substances may also be considered as a new class of antidiabetic drugs.

Introduction It is known that diabetes is associated with thrombosis and the activation of blood coagulation. ${ }^{1}$ Fibrinogen (FBG), a high-molecular-weight $(340 \mathrm{kDa})$ clottable protein of human blood, plays a role in hemostasis and thrombosis by serving as a precursor to fibrin. Fibrin clot, when stabilized by the catalytic action of factor XIII, is mechanically stronger than the non-cross-linked one and is also less vulnerable to premature fibrinolytic degradation. In addition to plasmatic components, the size and stability of a thrombus depends on blood cellular elements such as platelets, leukocytes, and red blood cells (RBCs). Moreover, the structure of the fibrin network and its susceptibility to fibrinolytic degradation depend on physical, biochemical, and genetic factors that operate under various pathological conditions. Thus, the clot architecture controls the size of its pores, which, in turn, determines the rate of blood perfusion making thin fibrin fibrils much less susceptible to fibrinolysis than the thick ones. ${ }^{2}$

Resistance of fibrin clots to enzymatic degradation, observed in numerous degenerative diseases, can now be explained in terms of the effect of hydroxyl radicals (HRs), which convert soluble human FBG into insoluble and plasmin-resistant polymer. These free radicals are, in turn, produced by poorly chelated iron ions accumulating in the circulation from the ingested food and/ 


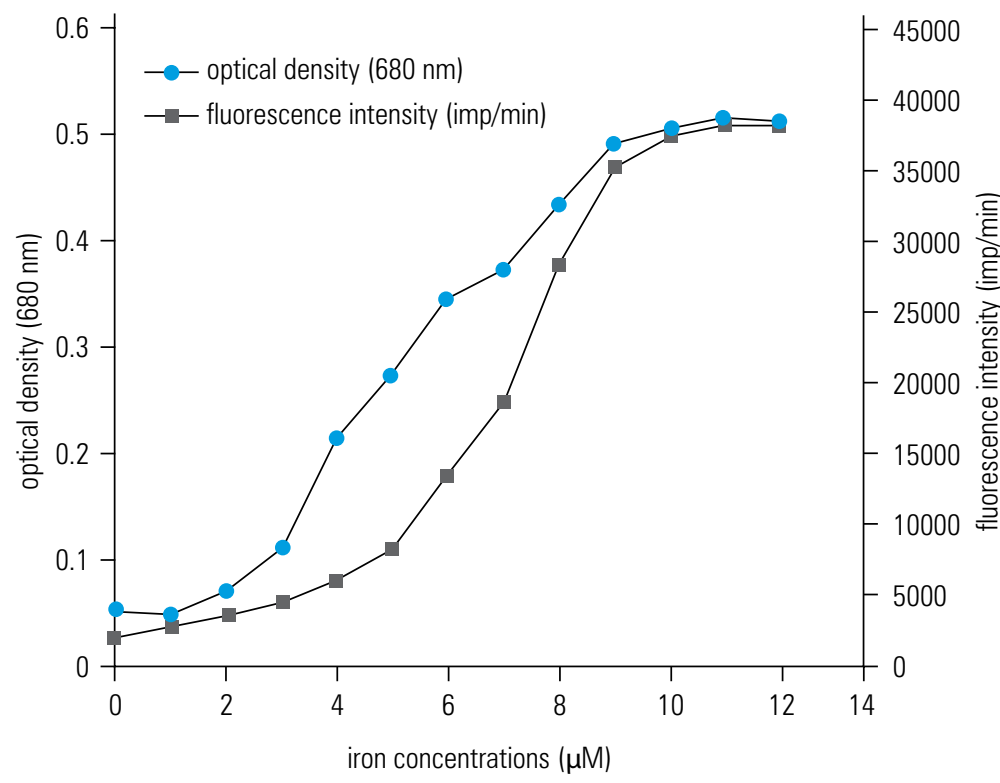

FIGURE 1 Polymerization of human fibrinogen (optical density), and hydroxyl radical generation (fluorescence intensity) as a function of iron (ferric chloride) concentration

or hemoglobin leaking from RBCs. HRs cause unfolding of FBG polypeptide chain(s) with the exposure of buried hydrophobic epitopes that form intermolecular bonds resistant to proteolytic degradation. Thus, it can be concluded that the commonly observed thrombolytic resistance of older thrombi might be caused by such a molecular modification induced by HRs generated under conditions of iron overload. ${ }^{3}$ In particular, the presence of insoluble and undegradable fibrin-like deposits may contribute to chronic inflammation and predisposition to thrombosis observed in diabetes. Soluble precursors, in the form of protofibrils, demonstrated in the blood of diabetic patients by means of scanning electron microscopy (SEM), may also be responsible for hemorheologic disturbances observed in this disease. Spontaneous aggregation of such protofibrils results in the formation of dense matted deposits (DMDs), which when fused to RBCs further contribute to the resistance of thrombi to fibrinolytic degradation. In this review, a novel pathway of blood coagulation is presented, and a number of natural substances are identified that may offer protection against diabetic complications.

The role of iron Iron is a transition metal that plays an essential role in many physiological functions in living organisms. Metabolism of iron in the human body is well controlled, so no large quantities of this metal are released at a given time. However, certain proportion of iron exists in blood in a free form in the so called labile pool. ${ }^{4}$ In human body, divalent iron, Fe(II), when released from RBCs is immediately oxidized to trivalent iron, Fe(III), by ferroxidase. In addition, trivalent iron is continuously accumulating in the body from external sources, specifically from the consumption of red meats. ${ }^{5}$ It should be emphasized that epidemiological data show a strong correlation between iron overload and diabetes as well as other degenerative diseases. ${ }^{6}$ Heme, which is released from oxidized hemoglobin, is an abundant source of redox active iron concentration, which is, in turn, regulated by ferritin and hepcidin. ${ }^{78}$ The release of redox-active iron into the bloodstream is toxic to the vasculature, contributing to the development of thrombosis. It was demonstrated that ferric chloride treatment of isolated mouse aorta perfused with whole blood is associated with endothelial denudation, collagen exposure, ${ }^{9}$ and when injected intravenously formed occlusive thrombi. ${ }^{10}$ Moreover, chronic hemolysis is known to lead to thrombosis and vascular complications. ${ }^{11}$ Relevant to these findings and pertinent to the diabetic nephropathy is a paper by Undas et al., ${ }^{12}$ describing altered fibrin clot properties in patients on hemodialysis. Labile iron was also shown to play a role in kidney disease that could be prevented with iron-chelating agents. ${ }^{13}$

Of note, although iron is known to generate HRs in the Fenton reaction in the presence of hydrogen peroxide and/or ascorbic acid, we showed that these most reactive free radicals are produced in the presence of ferric ions alone, according to the following reaction:

$$
\mathrm{Fe}^{3+}+\mathrm{HO}^{-} \rightarrow \mathrm{Fe}^{2+}+\mathrm{HO}
$$

This newly discovered reaction has significant implications for the understanding of oxidative stress. Thus, the addition of oxygen atoms to biological materials by means of aromatic hydroxylation can occur without any oxidizing agent. Consequently, real antioxidants such as vitamin $C$ may not only be ineffective in the prevention and treatment of degenerative disease, but in fact may potentiate their pathological consequences by participating in the Fenton reaction. It should be emphasized that the hydroxyl radical-modified FBG deposits are very difficult to be identified by conventional analytical methods, since they can only be detected by direct immunochemical staining methods.

Hydroxyl radicals and their pathological effects As shown in FIGURE 1, ferric ions cause the concomitant generation of HRs and polymerization of purified FBG. It is important to note that iron-induced polymers of FBG are very different from those produced by the enzymatic action of thrombin on purified FBG (FIGURE $2 A$ and B) and on human plasma (FIGURE $3 A$ and $B$ ).

While polymerization of fibrin monomers into fibrin occurs by means of the ionic bonds, hydroxyl radical-induced modification of FBG involves hydrophobic forces that irreversibly affect protein physicochemical properties rendering them refractory to proteolytic degradation. ${ }^{14}$ In addition, hydrophobic bonds, by contrast to the disulfide bridges, cannot be broken by the reduction in the presence of chaotropic solvents and boiling in alkali. The remarkable resistance of iron- 
FIGURE 2 Scanning electron microscopy micrographs of human fibrinogen treated with thrombin (A), and with ferric chloride (B)

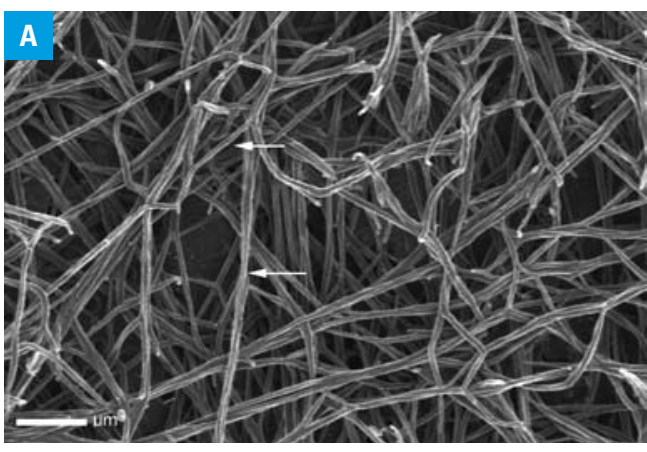

FIGURE 3 Normal human plasma after the addition of thrombin (A) and ferric chloride (B)

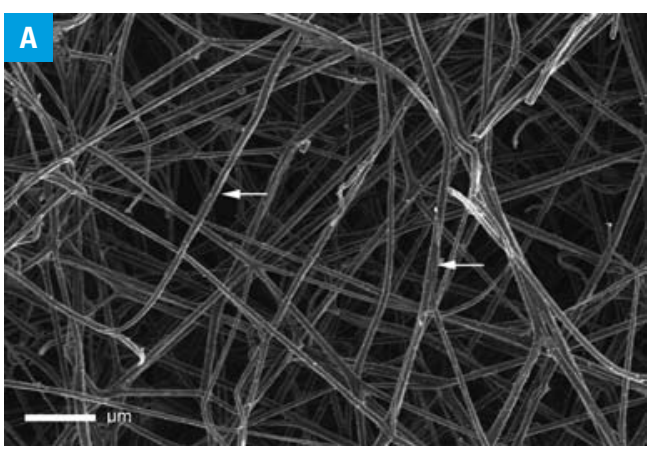

FIGURE 4 Polyacrylamide gel electrophoresis pattern of stabilized fibrin clot before (1) and after digestion with chymotrypsin (2); iron-generated fibrinogen polymer treated with chymotrypsin (3) and with sodium dodecyl sulfate-reducing agent (4)

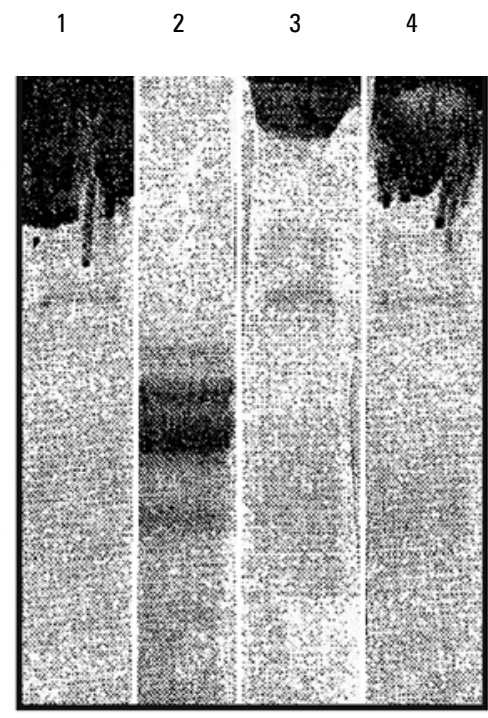

-induced polymer to such a drastic treatment indicates that it is bound together by the hydrophobic forces (FIGURE 4).

Fibrin fibers produced with thrombin are readily degradable to smaller polypeptide fragments by incubation with chymotrypsin (FIGURE 4, line 2 ), while the hydroxyl radical modified polymer remains intact after the enzymatic and chemical treatments (FIgure 4, lines 3 and 4). Thus, the failure to identify individual components of fibrin-like deposits that are formed under numerous pathological conditions can be explained in terms of the hydrophobic phenomenon. For example, because of its resistance to proteolytic degradation, it is not possible to correctly identify proteins such as those present in the fibrillar islet amyloid. ${ }^{15}$ Another nonreducible and nonextractable deposit containing FBG and human serum albumin could only be detected in silica
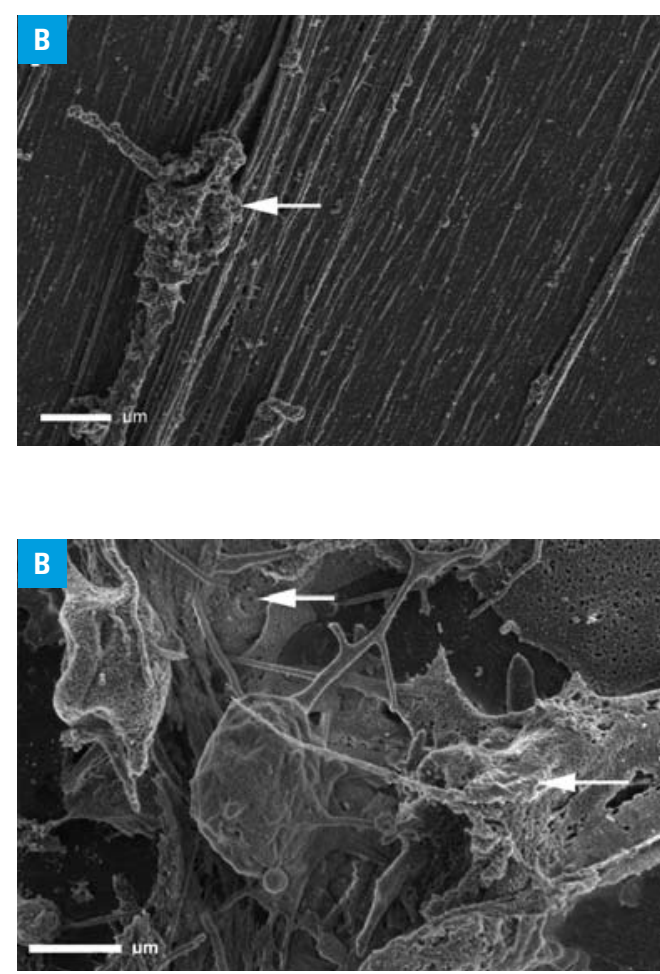

dust-induced lung nodules by immunochemical methods. ${ }^{16}$ Placenta of pregnant women is another example of a special function for a protease-resistant fibrinoid shown to be composed of FBG/ albumin complex. ${ }^{17} \mathrm{~A}$ similar type of an insoluble complex of FBG with albumin was also identified in the brain of patients with Alzheimer's disease. ${ }^{18}$ Therefore, it is possible that such complexes have been formed as a result of HR-induced modification of FBG and albumin molecules, thus explaining similarities in the pathogenesis of diabetes and Alzheimer's disease. ${ }^{19}$

Metabolic syndrome It is well established that patients with chronic kidney disease exhibit a higher burden of cardiovascular risk factors including inflammation, hypertension, dyslipidemia, hypercoagulability, and inhibition of fibrinolysis. ${ }^{20,21}$ Metabolic syndrome, defined by abdominal obesity, elevated blood pressure, fasting glucose, and triglycerides was reported to be associated with an increased risk of venous thromboembolism. ${ }^{22}$ In addition, diabetic patients were shown to have significantly higher levels of FBG, plasma viscosity, and red cell aggregation compared with nondiabetic patients. ${ }^{23}$ The role of blood coagulation and the persistent presence of fibrin in glomerular sclerosis were emphasized by Hertig and Rondeau in 2004. ${ }^{24}$ Fibrin-like material present in diseased glomeruli, often referred to as fibrinoid, identified by specific histochemical and/or immunological methods, ${ }^{25}$ is similar to that demonstred with SEM in plasma (FIGURE 5A) and whole blood (FIGURE 5B) of diabetic patients.

Marked alterations in fibrin clot properties found in patients on chronic peritoneal dialysis ${ }^{26}$ might be caused by hydroxyl modification of FBG structure as well. Evidence was also provided for 

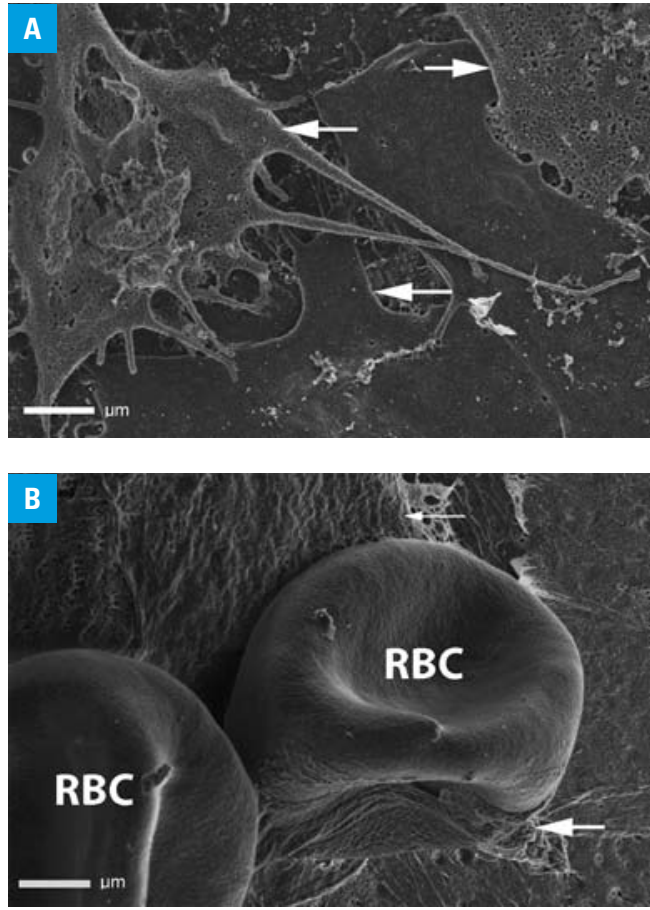

FIGURE 5 Scanning electron microscopy micrographs of diabetic plasma (A) and whole blood (B)

Abbreviations: RBC - red blood cell

the accumulation of free radical modified products prior to the development of diabetes. ${ }^{27}$

Iron may also contribute to type 2 diabetes by the hydroxyl radical-induced modification of insulin resulting in its increased hydrophobicity. ${ }^{28}$ Under physiological conditions, insulin circulates in blood in a monomeric form, but its hydrophobically bonded dimers exhibit impaired hormone-receptor interactions. ${ }^{29}$ In vitro exposure of insulin to HRs generated in the Fenton reaction caused its polymerization without affecting the immunological characteristics of this hormone (Lipiński, unpublished data). This phenomenon may explain why in hyperinsulinemic patients, there is an increased blood concentration of insulin, which is, however, biologically inactive due to the free radical-induced modification of its molecular structure. Moreover, interactions between modified FBG molecules and pancreatic $\beta$-cells may prevent the release of active insulin molecules into the circulation observed in type 2 diabetes.

Atherosclerosis It is well known that diabetes is associated with accelerated atherosclerosis. The presence of fibrin-like deposits in atherosclerotic plaques has been observed for a long time by numerous investigators, who have attributed them to the chronic activation of blood coagulation. Persistent presence of FBG-reactive antigenic material resistant to the action of proteases was identified in atherosclerotic plaques over 50 years ago. ${ }^{30}$ Subsequently, Smith ${ }^{31}$ had documented the existence of insoluble fibrin(ogen)-related antigens in the atherosclerotic intima. However, the mere activation of blood coagulation does not offer a satisfactory explanation for this commonly observed phenomenon, particularly in view of the fibrinolytic potential of human blood. It is known that the solid phase of thrombin-induced fibrin is a powerful stimulus for the release of tissue plasminogen activator, which, in turn, initiates effective fibrin degradation..$^{32}$ Therefore, it is obvious that fibrin-like deposits present in atherosclerotic plaques must have very different physicochemical properties, which determine their resistance to the enzymatic and chemical degradations.

Hemorheologic consequences It was discovered that plasma obtained from diabetic patients contained a macromolecular protein complex ${ }^{33}$ similar to advanced oxidation protein products found in uremic patients. ${ }^{34}$ Physicochemical properties of these 2 types of plasma complexes indicate their resemblance to protofibrils generated by the initial action of HRs on FBG molecules. There are 3 overlapping sets of mechanisms that are responsible for the cellular damage caused by soluble protein protofibrils: 1) disruption of cell membranes and their functions, 2) inactivation of normally folded functional proteins, and 3) binding to and inactivating components of the quality-control system of cells. At least 1 of these mechanisms may be involved in erythrocyte aggregation and deformability observed in diabetes, which explains hemorheologic disturbances and impaired blood circulation in this disease. . $^{35,36}$ It was first shown over 100 years ago by a Polish physician, Edmund Biernacki, that erythrocyte sedimentation was caused by plasma FBG. ${ }^{37}$ Subsequently, it was suggested that it is not FBG per se, but soluble fibrin monomer complexes, which play a critical role in this phenomenon. ${ }^{38}$ However, this particular mechanism would involve a continuous activation of blood coagulation in many chronic diseases, which is yet to be proved.

The discovery of hydroxyl radical-induced modification of FBG molecules offers a more plausible explanation for the mechanism of this important test. According to this concept, hydrophobic epitopes of RBC membranes interact with the hydrophobic regions of unfolded polypeptide chains of FBG, causing their aggregation and increasing their sedimentation. Interaction of RBC with DMDs in the blood of diabetic patients is shown in FIGURE $5 B$. One may argue that increased $\mathrm{RBC}$ sedimentation rate and/or their aggregation are not specific for diabetes, which certainly is the case, but so are the factors that contribute to the modification of FBG molecules. Apparently, manifestation of the interaction of hydrophobic protofibrils with RBCs in various degenerative conditions depends on genetic and epigenetic factors characteristic for a given disease. Yet a simple measurement of RBC sedimentation rate is very informative about the chain of reactions initiated by the excess of free iron in the human body. 
Iron-chelating agents and hydroxyl radical scavengers It is well recognized that numerous natural and/or synthetic substances containing phenolic rings in their structure scavenge HRs by means of aromatic hydroxylation. ${ }^{39}$ One of such recently discovered agents is resveratrol, present in red grapes and wine and shown to have beneficial effects in diabetes. ${ }^{40}$ The most widely used class of drugs containing phenolic rings, salicylates and their derivatives, have been shown to protect against free radical injury in vivo. ${ }^{41}$ The therapeutic effect of salicylic acid in diabetes was first observed almost 100 years ago, ${ }^{42}$ and has been confirmed only recently. ${ }^{43}$ Moreover, the protection against hydroxyl radical-induced damage in biological systems was shown to be offered by the use of natural polyphenolic class of substances, such as flavonoids and anthocyanins, present mostly in fruits and vegetables. ${ }^{44-46}$ In addition, genistein, a naturally occurring isoflavone present in soybeans, has recently been documented to be an effective hydroxyl radical scavenger by virtue of the addition of hydroxyl groups to double bonds of its aromatic rings. ${ }^{47}$ Interactions of polyphenols with the hydrophobic groups on the membranes of RBCs may also explain the protective effect on their aggregation and sedimentation. ${ }^{48}$

The health benefit of free radical scavengers in renal diseases has also been emphasized by other investigators..$^{49,50}$ In addition, there are a number of publications concerning the importance of fruit and vegetable diet in the prevention of cardiovascular disease, which has been attributed to their antioxidant properties. ${ }^{51,52}$ However, only very few of them have reducing properties, so they cannot be classified as antioxidants, and the remaining ones are either neutral or mild oxidants. Yet these natural phytochemicals, particularly polyphenols, have been shown to provide protection against numeorus chronic diseases by virtue of their free radical scavenging properties. ${ }^{53}$ The best known and already used in clinical practice is resveratrol, which neutralizes HRs by means of the aromatic hydroxylation reaction. Ferulic acid exerts a similar action against HRs. It belongs to the family of hydroxycinnamic acid with the chemical structure similar to curcumin..$^{54}$ Ferulic acid is present in the leaves and seeds of many plants, brown rice, whole wheat, oats, apples, artichokes, oranges, and pineapples. Curcumin (turmeric yellow polyphenol) was shown to exert anti-inflammatory activity, prevent atherosclerosis, and have cerebral protective effects. In addition to these natural substances, a synthetic compound, edaravone (3-methyl-1-pheny 1-pyrazolin-5-one), was also shown to counteract the development of streptozotocin-induced diabetes, supporting the concept that HRs may be a causative factor in this disease. ${ }^{55}$

It is generally believed that oxidative stress is involved in the pathogenesis of numerous chronic diseases, yet variety of substances which are not antioxidants have been shown to be of benefit in diabetes, specifically dietary flavonoid, quercetin, and phenolic compounds contained in food products. ${ }^{56}$ Another substance, $\alpha$-lipoic acid (6-thioctic acid), which is not an antioxidant per se, is a powerful scavenger of HRs and an iron chelator. ${ }^{57,58}$ Treatment with $\alpha$-lipoic acid was shown to have beneficial effects in diabetic patients with poor glycemic control and albuminuria. ${ }^{59}$ The beneficial effect of fish consumption is another example of an oxidative stress paradox. In view of the presence of polyunsaturated fatty acids in fish oils, these should be more prone to damaging effect of oxidation. Yet, they exert protective effects due to the ability of double bonds to scavenge HRs by their conversion to hydroxyl-fatty acids. ${ }^{60}$

It should be noted that the phenolic moieties of numerous natural products, such as anthocyanis can both chelate iron and scavenge HRs and in this way improve insulin sensitivity. ${ }^{61-63}$ In addition to exogenous substances, endogenous factors, specifically human serum albumin, can also regulate blood iron availability. Albumin is the most abundant protein present in human blood plasma at the concentrations of 3.4 to $5.4 \mathrm{~g} / \mathrm{dl}$. It is produced in the liver and constitutes about half of the blood serum protein being the most soluble and hydrophilic. Albumin transports hormones, fatty acids, and other compounds, buffers $\mathrm{pH}$, and effectively binds iron, among other functions. Decreased levels of albumin may be responsible for the increased concentration of iron taken up from dietary heme and non-heme sources, thus contributing to type 2 diabetes and presenting the risk for gestational diabetes. ${ }^{64}$ Human serum albumin is known to be a good substrate for glucose-induced glycation, which subsequently introduces additional storage sites for iron. ${ }^{65}$ By contrast to native albumin, protein-bound iron retains its redox properties and hence may induce free radical stress in diabetes. ${ }^{66}$ Thus, in addition to measuring glycated hemoglobin in the blood of diabetic patients, it seems to be reasonable to determine the level of glycated albumin that may more accurately reflect changes in plasma glucose during short-term and postprandial plasma conditions. ${ }^{67}$

Conclusions In this review, we postulate that the iron-induced generation of HRs and their subsequent interaction with FBG represent a novel, albeit pathological, pathway of blood coagulation. We also suggest that soluble, modified FBG molecules, in the form of protofibrils, interact with RBCs causing hemorheologic disturbances observable in diabetes. In addition, fully polymerized DMDs irreversibly trap RBCs, thus further disturbing proper oxygen delivery to tissues and organs in diabetes. In addition, hydroxyl radical-induced alteration of insulin tertiary structure may also be a causative factor in the metabolic syndrome. While such profound structural modifications of FBG and insulin molecules are irreversible, they can be prevented by dietary intake of hydroxyl radical scavengers and/or iron-chelating agents such as polyphenols that are present in 


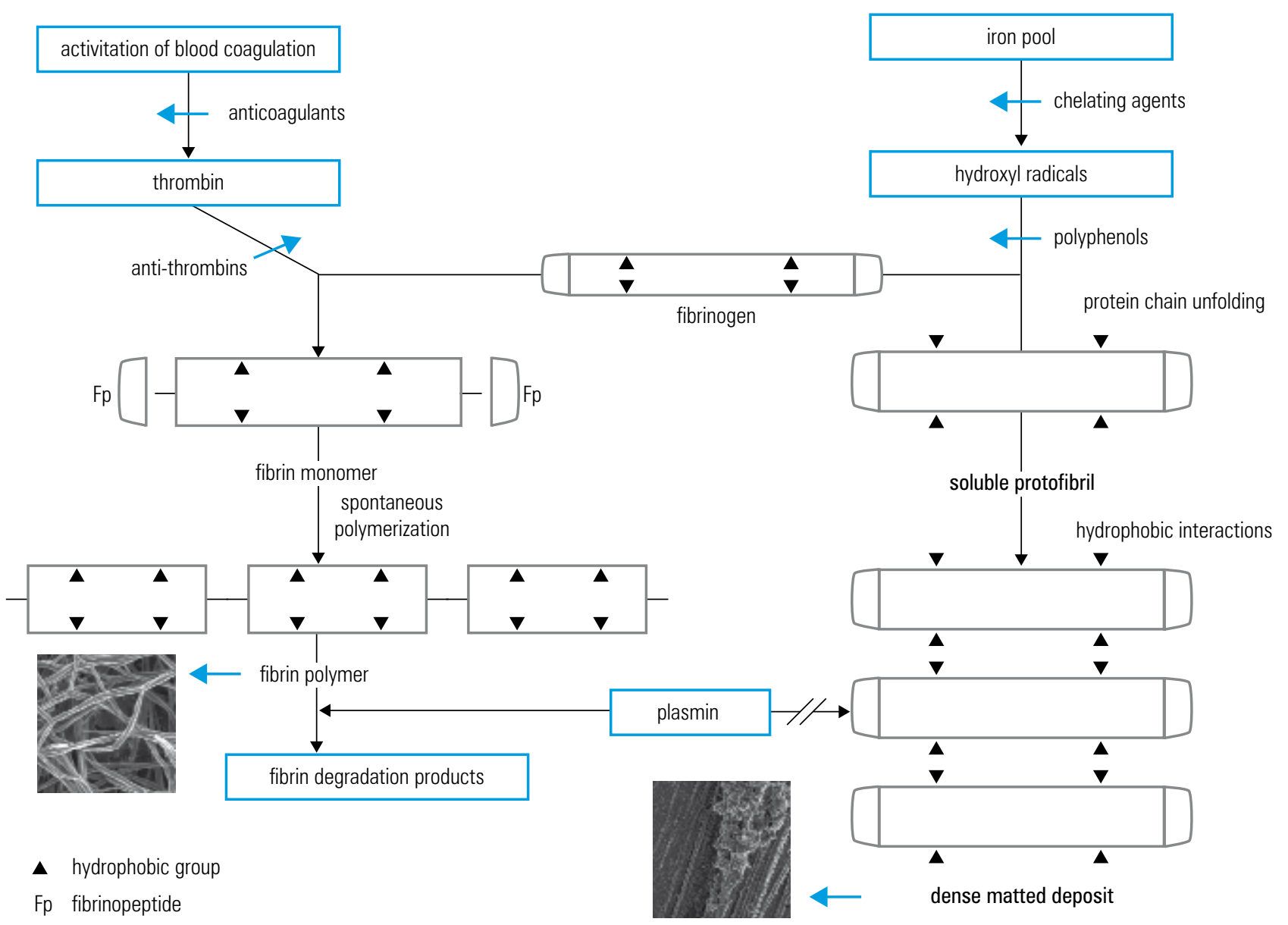

FIGURE 6 Schematic representation of the conversion of soluble fibrinogen into insoluble polymers. Thrombin-induced reaction results in the formation of fibrin strands (left insert) that are degradable with plasmin. By contrast, iron-induced dense matted deposits (right insert) are resistant to proteolysis. The thrombin pathway, operating in normal blood coagulation, can be inhibited with anticoagulants (calcium-binding agents) and/or with antithrombins such as heparin. Iron-induced blood coagulation can be prevented by hydroxyl radical scavengers (e.g., salicylates), and/or iron chelating agents (polyphenols).

many berries. The beneficial effect of salicylates, first reported over 100 years ago, still remains clinically underestimated despite the known fact that this phenolic substance is an effective scavenger of HRs. A quantum leap in the understanding of this very important problem is therefore needed to utilize the accumulated knowledge for the benefit of human health. We suggest that the use of SEM is a very effective tool for the visualization of circulatory consequences of the interaction of iron-induced HRs with human FBG.

The most poignant consequence of the in vivo formation of iron-induced fibrin-like deposits is their resistance to fibrinolysis, which otherwise is very effective in clearing thrombin-induced clots. It should be emphasized that the susceptibility to proteolytic degradation is governed by the type of hydrophobic interactions operating in these 2 FBG polymers (FIGURE 6). Thus, intramolecular hydrophobic forces are responsible for the maintenance of the tertiary structure of native fibrin(ogen), whereas intermolecular hydrophobic bonds are involved in the formation of modified FBG polymers (DMDs).

However, it is not currently understood why a counterbalancing mechanism, similar to that acting in the conventional blood clotting, was not evolutionary created for the iron-induced pathway. It is quite possible that iron overload and dietary deficiencies in the intake of chelating and/or HR-scavenging agents are relatively recent phenomena, to which humans had no time to adapt. Consequently, it seems that the epidemics of diabetes and cardiovascular diseases observed in the last centuries is the result of a dramatic departure of human race from the so called primitive yet natural lifestyle. This notion is supported by the observation that people whose diet includes fruit, vegetables, and fish supplemented with red wine (so called Mediterranean diet) have lower cardiovascular mortality and morbidity rate than those living in the developed countries and not following the above diet. ${ }^{68}$

\section{REFERENCES}

1 Hess K, Grant PJ. Inflammation and thrombosis in diabetes. Thromb Haemost. 2011; 105: S43-54.

2 Undas A, Kolarz M, Kopeć G, Tracz W. Altered fibrin clot properties on long-term haemodialysis: relation to cardiovascular mortality. Nephrol Dial Transplant. 2008; 23: 2010-2015.

3 Lipinski B. Hydroxyl radical and its scavengers in health and disease. Oxid Cell Med Longev. 2011 Jul 17. Epub ahead of print.

4 Kruszewski M. The role of labile iron pool in the cardiovascular disease. Acta Biochem Pol. 2004; 51: 471-480.

5 Tappel A. Heme of consumed red meat can act as a catalyst of oxidative damage and could initiate colon, breast and prostate cancers, heart disease and other diseases. Med Hypotheses. 2007; 68: 562-564. 
6 Kell DB. Towards a unifying, systems biology understanding of large-scale cellular death and destruction caused by poorly liganded iron: Parkinson's, Huntingston's, Alzheimer's, prions, bactericides, chemical tox cology and others as examples. Arch Toxicol. 2010; 84: 825-889.

7 Reeder BJ, Svistunenko DA, Cooper CE, Wilson MT. The radical and re dox chemistry of myoglobin and hemoglobin: from in vitro studies to human pathology. Antioxid Redox Signal. 2004; 6: 954-966.

8 Balla J, Vercellotti GM, Jeney V, et al. Heme, heme oxygenase, and ferritin: how the vascular endothelium survives (and dies) in an iron-rich environment. Antioxid Redox Signal. 2007; 9: 2119-2137.

9 Woollard KJ, Sturgeon S, Chin-Dusting JP, et al. Erythrocyte hemolysis and hemoglobin oxidation promotes ferric choride-induced vascular injury. J Biol Chem. 2009; 284: 13110-13118.

10 Eckly $\mathrm{A}$, Hechler $\mathrm{B}$, Freund $\mathrm{M}$, et al. Mechanism underlying $\mathrm{FeCl}_{3}$-induced arterial thrombosis. J Thromb Haemost. 2011; 9: 779-789.

11 Belcher JD, Beckman JD, Balla G, et al. Heme degradation and vascular injury. Antioxid Redox Signal. 2010; 12: 233-248.

12 Undas A, Szuldrzynski K, Stepien E, et al. Reduced clot permeability and susceptibility to lysis in patients with acute coronary syndrome: effects of inflammation and oxidative stress. Atherosclerosis. 2008; 196: 551-557.

13 Shah SV, Rajapurkar MM. The role of labile iron in kidney diseases and treatment with chelation. Hemoglobin. 2009; 33: 378-385.

14 Lins $\mathrm{L}$, Brausseur $\mathrm{R}$. The hydrophobic effect in protein folding. FASEB J. 1995; 9: 535-540.

15 Badman MK, Pryce RA, Charge SBP, et al. Fibrillar islet amyloid poly peptide (amylin) is internalized by macrophages but resists proteolytic degradation. Cell Tissue Res. 1998; 291: 285-294

16 Kim YM, Chung SI, Lee SY. Roles of plasma proteins in the formation of silicotic nodules in rats. Toxicol Lett. 2005; 158: 1-9.

17 Wasiutyński A, Wiczyński GM, Morton M, et al. Fibrinogen/fibrin and albumin colocalize on the surface of placental villi - a novel element of fetomaternal barrier? Ann Diagn Paediatr Pathol. 2002; 6: 123-127.

18 Lipinski B, Sajdel-Sulkowska EM. New insight into Alzheimer's disease: demonstration of fibrin(ogen)-serum albumin insoluble deposits in brain tissue. Alzheimer Dis Assoc Disord. 2006; 20: 323-326.

19 Messier C, Gangnon M. Glucose regulation and cognitive functions: relation to Alzheimer's disease and diabetes. Behav Brain Res. 1996; 75: 1-11.

20 Adams RL, Bird RJ. Review article: Coagulation cascade and therapeutics advance: relevance to nephrology. Part 1: Overview of coagulation, thrombophilias and history of anticoagulants. Nephrology (Carlton). 2009; 14: 462-470.

21 Grant PJ. Diabetes mellitus as a prothrombotic condition. J Intern Med. 2007; 262: 157-172

22 Ay C, Tengler T, Vormittag R, et al. Venous thromboembolism - a manifestation of the metabolic syndrome. Haematologica. 2007; 92: 374-380.

23 Jax TW, Peters AJ, Plehn G, Schoebel FC. Hemostatic risk factors in patients with coronary artery disease and type 2 diabetes - a two yea follow-up of 243 patients. Cardiovasc Diabetol. 2009; 8: 48-53

24 Hertig $A$, Rondeau E. Role of the coagulation/fibrinolysis system in fibrin-associated glomerular injury. J Am Soc Nephrol. 2004,15: 844-853.

25 Takemura T, Yoshika K, Akano N, et al. Glomerular deposition of cross-linked fibrin in human kidney disease. Kidney Int. 1987; 32: 102-111.

26 Sjøland JA, Sidelmann JJ, Brabrand M, et al. Fibrin clot structure in patients with end-stage renal disease. Thromb Haemost. 2007; 98: 339-345.

27 Matteucci E, Giampietro 0. 0xidative stress in families of type 1 diabetic patients. Diabetes Care. 2000; 23: 1182-1186.

28 Inoue $\mathrm{H}$, Hirobe $\mathrm{M}$. Disulfide cleavage and insulin denaturation by active oxygen in copper(II)/ascorbic acid system. Chem Pharm Bull. 1986; 34 1075-1079.

29 Pocker Y, Biswas SB. Self-association of insulin and the role of hydrophobic bonding: A thermodynamic model of insulin dimerization. Biochemistry. 1981; 20: 4354-4361.

30 Duguid JB. Thrombosis as a factor in the pathogenesis of coronary atherosclerosis. J Pathol Bacteriol. 1946; 58: 207-212.

31 Smith EB. Fibrin deposition and fibrin degradation products in atherosclerotic plaques. Thromb Res. 1994; 75: 329-335.

32 Lipinski B, Nowak A, Gurewich V. Fibrinolysis versus fibrinogenolysis of man: resistance of fibrinogen to breakdown by fibrinolytic activity induced by venous occlusion. Experientia. 1974: 30: 84-86.

33 Lipinski B, Federman SM, Krolewski AS. Plasma macromolecular protein complex: Interaction with fibrin and fibrinolysis. Thromb Res. 1995; 78: $461-465$

34 Witko-Sarsat V, Friedlander M, Capeillère-Blandin C, et al. Advanced oxidation protein products as a novel marker of oxidative stress in uremia. Kidney Int. 1996; 49: 1304-1313.

35 Ford ES. Leukocyte count, erythrocyte sedimentation rate, and diabetes incidence in a national sample of US adults. Am J Epidemiol. 2002; 155 57-64.

36 Singh M, Shin S. Changes in erythrocyte aggregation and deformability in diabetes mellitus: a brief review. Indian J Exp Biol. 2009; 47: 7-15.
37 Biernacki E. [Spontaneous blood sedimentation as a scientific and practical clinical test]. Gazeta Lekarska. 1897; 17: 962-964. Polish.

38 Lipiński B, Worowski K, Myśliwiec M, Farbiszewski R. Erythrocyte sedimentation and soluble fibrin monomer complexes. Thromb Diathes Haemorrh. 1969; 21: 196-202.

39 Ghiselli A, Laurenti O, De Mattia G, et al. Salicylate hydroxylation as an early marker of in vivo oxidative stress in diabetic patients. Free Radic Biol Med. 1992; 13: 621-626.

40 Szkudelski T, Szkudelska K. Anti-diabetic effects of resveratrol. Ann NY Acad Sci. 2011; 1215: 34-39.

41 Kim MK, Kim Y-J, Fillmore JJ, et al. Prevention of fat-induced insulin re sistance by salicylates. J Clin Invest. 2001; 108: 437-446.

42 Williamson RT. On the treatment of glycosuria and diabetes mellitus with sodium salicylate. Br Med J. 1901; 1: 760-762.

$43 \mathrm{Kim}$ JA. Mechanisms underlying beneficial health effects of tea catechins to improve insulin resistance and endothelial dysfunction. Endocr Metab Immune Disord Drug Targets. 2008; 8: 82-88.

44 Benedek B, Weniger B, Parejo I, et al. Antioxidant activity of isofavones and biflavones isolated from Godoya antioquiensis. Arzneimittelforschung. 2006; 56: 661-664.

45 Sikora J, Broncel M, Markowicz M, et al. Short-term supplementation with Aronia melanocarpa extract improves platelet aggregation, clotting, and fibrinolysis in patients with metabolic syndrome. Eur J Nutr. 2011 Aug 18. [Epub ahead of print]

46 Stowe CB. The effects of pomegranate juice consumption on blood pressure and cardiovascular health. Complement Ther Clin Pracr. 2011; 17 $113-115$

47 Zielonka J, Gebicki J, Grynkiewicz G. Radical scavenging properties of genistein. Free Radic Biol Med. 2003; 35: 958-965.

48 Cyboran S, Oszmański J, Kleszczyńska H. Interaction between plant polyphenols and the erythrocyte membrane. Cell Mol Biol Lett. 2012; 17: 77-88.

49 Ho E, Bray TM. Antioxidants, NFkappaB activation, and diabetogenesis. Proc Soc Exp Biol Med. 1999; 222: 205-213.

50 O'Brian RC, Luo M, Balazs N, Mercuri N. In vitro and in vivo antioxidant properties of gliclazide. J Diabetes Complications. 2000; 14: 201-206.

51 Calabrese V, Guagliano E, Sapienza M, et al. Redox regulation of ceIular stress response in neurodegenerative disorders. Ital J Biochem. 2006 55: 263-282.

52 Dauchet L, Amouyel P, Dallongeville J. Fruits, vegetables and coronary heart disease. Nat Rev Cardiol. 2009; 6: 599-608.

53 Stocklet JC, Chataigneau T, Ndiaye M, et al. Vascular protection by dietary polyphenols. Eur J Pharmacol. 2004; 500: 299-313.

54 Srinivasan M, Sudheer AR, Menon VP. Ferulic Acid: therapeutic potential through its antioxidant property. J Clin Biochem Nutr. 2007; 40: 92-100. 55 Fukudome D, Matsuda M, Kawasaki T, et al. The radical scavenge edaravone counteracts diabetes in multiple low-dose streptozotocin-treated mice. Eur J Pharmacol. 2008; 583: 164-169.

56 Doi K, Suzuki Y, Nakao A, et al. Radical scavenger edaravone developed for clinical use ameliorates ischemia/reperfusion in jury in rat kidney. Kidney Int. 2004; 65: 1714-1723.

57 Packer L, Kraemer K, Rimbach G. Molecular aspects of lipoic acid in the prevention of diabetes complications. Nutrition. 2001; 17: 888-895.

58 Golbidi S, Badran M, Laher I. Diabetes and lipoic acid. Front Pharmacol. 2011; 2: 69.

59 Borcea V, Nourooz-Zadeh J, Wolff SP, et al. Alpha-lipoic acid decreases oxidative stress even in diabetic patients with poor glycemic control and albuminuria. Free Radic Biol Med. 1999; 26: 1495-1500.

60 Czapski G. Reactions of .OH. Meth Enzymol. 1984; 105: 209-215

61 Capellini MD, Taher A. Deferasirox (Exjade) for the treatment of iron overload. Acta Hematol. 2009; 122: 165-172.

62 Brasnyó $\mathrm{P}$, Molnár GA, Mohás $\mathrm{M}$, et al. Resveratrol improves insulin sensitivity, reduces oxidative stress and activates the Akt pathway in type 2 diabetic patients. Br J Nutr. 2011; 106: 383-389.

63 Fraga CG, Oteiza PI. Iron toxicity and antioxidant nutrients. Toxicology. 2002; 180: 23-32

64 Diu C, Zhang C, Gelaye B, et al. Gestational diabetes mellitus in relation to maternal dietary heme iron and nonheme iron intake. Diabetes Care. 2011; 34: 1564-1569.

65 Zwang TJ, Gormally MV, Johal MS, Sazinsky MH. Enhanced iron avaiability by protein glycation may explain higher infection rates in diabetes. Biometals. 2012; 25: 237-2

66 Whaley-Connell A, McCullough PA, Sowers JR. The role of oxidative stress in the metabolic syndrome. Rev Cardiovasc Med. 2011; 12: 21-29.

67 Koga M, Kasayama S. Clinical impact of glycated albumin another glycemic control marker. Endocr J. 2010; 57: 751-762.

68 Mascitelli L, Goldstein MR. Mediterranean diet, lower body iron stores and metabolic syndrome. Int J Clin Pract. 2011; 65: 1110. 


\title{
Nowy mechanizm krzepnięcia krwi wywołanego żelazem - znaczenie w cukrzycy i jej powikłaniach*
}

\author{
Boguslaw Lipinski ${ }^{1}$, Etheresia Pretorius ${ }^{2}$ \\ 1 Joslin Diabetes Center, Harvard Medical School, Boston, Stany Zjednoczone \\ 2 Department of Physiology, Faculty of Health Sciences, University of Pretoria, Arcadia, Republika Południowej Afryki
}

\section{SŁOWA KLUCZOWE}

cukrzyca, fibrynogen, polifenole, rodniki hydroksylowe, żelazo
Adres do korespondencji: Boguslaw Lipinski, PhD, Joslin Diabetes Center, One Joslin PI., Boston, MA 02215, USA, tel.: +1-617-527-1395,

fax: + 1-617-309-2667

e-mail: b.lipinski2006@rcn.com

Praca wpłynęła: 28.10.2011.

Przyjęta do druku: 03.02.2012.

Nie zgłoszono sprzeczności

interesów.

Pol Arch Med Wewn. 2012

122 (3): 117-122

Copyright by Medycyna Praktyczna, Kraków 2012

*Pamięci prof. dr hab. med. Zofil

Kuratowskiej, ambasadora Polski

w Republice Południowej Afryki

(1997-1999).

\section{STRESZCZENIE}

Fibrynogen (FBG) jest wielkocząsteczkowym białkiem osocza i prekursorem enzymatycznie wytwarzanej fibryny. Jak ostatnio wykazano, FBG może być również przekształcony w nierozpuszczalny fibrynopodobny polimer pod wpływem nieenzymatycznego działania rodników hydroksylowych (hydroxyl radicals - HR). Te wolne rodniki są wytwarzane w wyniku reakcji między wodorotlenowymi grupami wody a trójwartościowymi jonami żelaza, bez udziału jakiegokolwiek czynnika redoks. Interakcja między HR a FBG zachodzi w układzie oczyszczonym oraz w osoczu i w pełnej krwi. Analiza za pomocą elektronowego mikroskopu skaningowego (scanning electron microscopy - SEM) skrzepów fibrynowych wytworzonych przez trombinę oraz w obecności chlorku żelaza wykazała ich zasadnicze różnice morfologiczne i różną podatność na enzymatyczną degradację. Włókna fibrynowe powstałe pod wpływem trombiny są grube i łatwo rozkładane przez chymotrypsynę, natomiast gęsto upakowane depozyty fibryny powstające pod wpływem jonów żelaza są, z powodu obecnych w nich międzycząsteczkowych wiązań hydrofobowych, w znacznym stopniu oporne na degradację enzymatyczną i chemiczną. Postulujemy zatem, że ta katalizowana przez żelazo reakcja przedstawia nowy mechanizm krzepnięcia krwi w chorobach degeneracyjnych. Za pomocą analizy SEM wykazaliśmy obecność takich gęsto upakowanych złogów fibryny we krwi chorych na cukrzycę. Stan nadkrzepliwości krwi i powikłania sercowo-naczyniowe spotykane w cukrzycy można zatem tłumaczyć stałym działaniem wolnego żelaza in vivo. Co więcej, wykazaliśmy, że jony żelazowe wytwarzają rozpuszczalne protofibryle, które wiążą się do hydrofobowych rejonów na błonach komórkowych czerwonych krwinek. Zjawisko to może tłumaczyć zaburzenia reologiczne krwi obserwowane u chorych z zespołem metabolicznym oraz innymi chorobami wywołanymi nadmiarem żelaza. Należy zaznaczyć, że HR mogą być skutecznie zmiatane przez substancje fenolowe, dlatego pewne naturalne substancje polifenolowe, które również zmiatają $\mathrm{HR}$, można uznać za substancje o potencjalnym działaniu przeciwcukrzycowym. Ponadto naturalne lub syntetyczne substancje wiążące żelazo można również rozpatrywać jako nową klasę leków przeciwcukrzycowych. 